\title{
A $\beta-42$ deposition significantly increases the insolubility of synaptophysin in the brains of hAPPsw/hPS2m double transgenic mice
}

\author{
DAE YOUN HWANG ${ }^{1}$, SEUNG WAN JEE ${ }^{2}$, SU HAE LEE ${ }^{2}$, CHANG JUN BAE $^{2}$, JUN SEO GOO ${ }^{1}$, \\ JEE EUN KIM ${ }^{1}$, SO HEE NAM ${ }^{1}$, SUN IL CHOI ${ }^{1}$, HYE RYUN LEE ${ }^{1}$, SUN BO SHIM ${ }^{2}$, \\ MI HEE PARK ${ }^{3}$, JIN TAE HONG ${ }^{3}$ and HYE SUNG KIM ${ }^{4}$
}

\author{
${ }^{1}$ Department of Biomaterials Science, College of Natural Resources and Life Science, Pusan National University, \\ Miryang 627-706; ${ }^{2}$ Department of Laboratory Animal Resources, National Institute of Food and Drug \\ Evaluation, Seoul 122-704; ${ }^{3}$ College of Pharmacy, Chungbuk National University, Chungju 361-763; \\ ${ }^{4}$ Department of Nanomaterials Engineering, College of Nanoscience and Nanotechnology, \\ Pusan National University, Miryang 627-706, Republic of Korea
}

Received January 21, 2011; Accepted March 14, 2011

DOI: 10.3892/ijmm.2011.673

\begin{abstract}
Synaptophysin is a synaptic vesicle glycoprotein involved in the regulation process for neurotransmitter release, which is distributed throughout neuroendocrine cells and all neurons in the brain and spinal cord. In an effort to determine whether amyloid $\beta$ (A $\beta$ )-42 peptides could influence the quantity and biochemical properties of synaptophysin, alterations in the levels of the synaptophysin protein in various soluble fractions were detected in the brains of four genotypes of transgenic mice ( $\mathrm{Tg}$ ) including Non-Tg, neuron-specific enolase (NSE)-hPS2m, NSE-hAPPsw and $\mathrm{hAPPsw} / \mathrm{hPS} 2 \mathrm{~m}$ double Tg mice. Among the four genotypes of Tg mice, the highest levels of $A \beta-42$ peptides were noted in hAPPsw/hPS2 $m$, followed by NSE-hAPPsw, NSE-hPS2 $m$ and Non-Tg mice. In the brains of these mice displaying different levels of $A \beta-42$ peptides, the levels of soluble synaptophysin were reduced significantly only in the hAPPsw/hPS2m double $\mathrm{Tg}$ mice compared to the Non-Tg mice. However, immunohistochemical analysis revealed no differences in the levels of total synaptophysin protein between the neocortex and hippocampus of the four different genotypes of mice. Western blot analysis using four-step fractions with differing solubility revealed a marked decrease in synaptophysin levels in the Tris-buffer saline fraction of hAPPsw/hPS2m double Tg mice and a significant increase in the formic acid fraction, relative
\end{abstract}

Correspondence to: Dr Hye Sung Kim, Department of Nanomaterials Engineering, College of Nanoscience and Nanotechnology, Pusan National University, 50 Cheonghak-ri, Samnangjin-eup Miryang-si, Gyeongsangnam-do 627-706, Republic of Korea

E-mail: rabbitkim5584@gmail.com

Key words: Alzheimer's disease, synaptophysin, amyloid $\beta-42$ peptide, solubility, transgenic mice to the Non-Tg mice. The results obtained from our in vivo experiments in mice are identical to the results observed in SK-N-MC cells treated with $100 \mathrm{nM} \mathrm{A} \beta-42$ peptides. Therefore, our experiments collectively suggest that $A \beta-42$ peptides may alter the solubility without changing the total amount of synaptophysin.

\section{Introduction}

Synaptophysin is a $38-\mathrm{kDa}$ calcium-binding glycoprotein which is distributed throughout the neuronal synaptic vesicles and certain endocrine cells (1-3). Synaptophysin is a valuable marker protein for synaptic vesicles and terminals at the microscopic level. Functionally, it appears to play a crucial role in exocytosis, facilitating the fusion of synaptic vesicles to the presynaptic membrane during neurotransmitter release $(4,5)$. Levels of synaptophysin protein are enhanced during synaptogenesis $(6,7)$, and are thus recognized as markers for synaptic re-organization following denervation $(8,9)$. In particular, in the auditory system, synaptophysin is present in the synaptic terminals of the efferent fibers projecting to the cochlea and sensory axons, and their putative termination in the central nervous system $(8,10)$.

Synaptophysin immunoreactivity (SYN-IR) has been previously reported in Tg mice with Alzheimer's disease (AD). Reduced, increased, or unchanged immunoreactivity has been described, depending on the mouse strain, transgene type, and age. An early study reported that 8 -month-old platelet-derived growth factor promoter expressing amyloid precursor protein (PDAPP) Tg mice harboring a human $\beta$-amyloid precursor protein (hAPP) V717F gene under the control of the plateletderived growth factor B promoter displayed significantly reduced SYN-IR within the dentate gyrus molecular layer (11). In another study, APPind H6 and wild-type hAPP Tg mice also displayed reduced SYN-IR in the dentate gyrus, despite displaying greater brain $A \beta$ deposition (12). However, 
a subsequent study conducted with PDAPP heterozygous Tg mice aged 3-4, 6-7, and 10-12 months reported elevated SYN-IR within the cerebral cortex (13). Other studies using AD Tg mice displaying $A \beta$ deposition and neuritic plaques have detected no alterations in SYN-IR. Irizarry et al (14) observed that SYN-IR expression remained unaltered in 18-month PDAPP Tg mice. A study conducted with 16-monthold Tg2576 mice also showed that SYN-IR was unaltered in the dentate gyrus, CA1, cingulate cortex, entorhinal cortex, and thalamus (15). Twelve-month-old hAPPsw+human Presenilin 1 (hPS1) Tg mice displayed no loss of SYN-IR in the frontal neocortex or dentate gyrus, although the hAPPsw+hPS1 double $\mathrm{Tg}$ mice exhibited a greater amyloid deposition than the single APPsw or hPS1 Tg mice (16).

Therefore, resolution of this disparity requires investigations of the changes in the biochemical properties of synaptophysin induced by $A \beta-42$ peptides. In this study, the synaptophysin levels were determined in four different soluble fractions collected from the brains of AD mouse models, using a specific antibody. The results are consistent with the notion that the deposition of $\mathrm{A} \beta-42$ peptide may be strongly correlated with the solubility of synaptophysin in the cortex and hippocampus in the AD-affected brain.

\section{Materials and methods}

Animal care and use. All animal experimental procedures employed in this study were approved by the Institutional Animal Care and Use Committee (IACUC) of the Korea FDA and Pusan National University. All mice were supplied by the breeding center of a Korea FDA facility and were handled in a Korea FDA accredited animal facility in accordance with the AAALAC International Animal Care policy (Accredited Unit, Korea Food and Drug Administration: Unit no. 000996) and PNU-Laboratory Animal Resources Center. The mice were housed in cages under a strict light cycle (lights on at 06:00 $\mathrm{h}$ and off at $18: 00 \mathrm{~h}$ ) at $23 \pm 1^{\circ} \mathrm{C}$ and a relative humidity of $50 \%$. Additionally, all mice were given a standard irradiated chow diet (Purina Mills Inc., USA) ad libitum and maintained in a specified pathogen-free state.

Production and identification of hAPPsw/hPS2m double Tg mice. hAPPsw/hPS $2 \mathrm{~m}$ double Tg mice were generated from male NSE-hAPPsw and female NSE-hPS2m Tg mice. The NSE-hAPPsw Tg mice were developed via the insertion of the hAPPsw gene under the control of an NSE promoter. These $\mathrm{Tg}$ mice display the neuropathological phenotype typical of AD, which includes behavioral dysfunction, A $\beta-42$ deposition, elevated Tau phosphorylation and Cox-2 induction at 12 months of age (17). The NSE-hPS2m Tg mice also express human mutant Presenilin 2 (hPS2, N141I), under the control of the NSE promoter (18). These Tg mice exhibit behavioral dysfunction, $\mathrm{A} \beta-42$ deposition, and caspase- 3 and Cox-2 induction at 12 months of age.

Three weeks after birth, offspring with four different genotypes, hAPPsw/hPS2m double, single NSE/hAPPsw, $\mathrm{NSE} / \mathrm{hPS} 2 \mathrm{~m}$ and Non-Tg, were identified via polymerase chain reaction (PCR) analysis using APP and PS2-specific primers. The primer sequences were as follows: APP-specific primers, sense, 5'-GAGGAAGAAGTGTGTGATGAG-3' and antisense,
5'-CACGATGACGCTGATCATGATG-3'; and PS2-specific primers, sense, 5'-TCTAGATCGCGATGCTGC-3' and antisense, 5'-GTCTAGAGTCTAGTTCTGCATC-3'. The PCR consisted of 25 cycles of denaturation for $30 \mathrm{sec}$ at $95^{\circ} \mathrm{C}$, annealing for $30 \mathrm{sec}$ at $62^{\circ} \mathrm{C}$, and extension for $45 \mathrm{sec}$ at $72^{\circ} \mathrm{C}$. The amplified PCR products were loaded on a $1.0 \%$ agarose gel in a buffer containing $30 \%$ glycerol, $0.25 \%$ bromophenol blue (BPB), and $0.25 \%$ xylene cyanol (XC), and electrophoresed. The resolved bands were visualized with ethidium bromide (EtBr).

Preparation of total soluble protein from mouse brain. Frozen brain tissues were chopped with scissors and homogenized in lysis solution [50 mM Tris ( $\mathrm{pH} 8.0$ ), $150 \mathrm{mM} \mathrm{NaCl}, 0.02 \%$ sodium azide, $0.2 \%$ sodium dodecyl sulfate (SDS), $1 \%$ Igepal$630,0.5 \%$ sodium fluoride, $0.5 \%$ sodium deoxycolate, $0.5 \mathrm{mM}$ EDTA, $0.1 \mathrm{mM}$ EGTA and proteinase inhibitor] using a glass homogenizer. The soluble homogenate was separated from the total lysate mixture via $15 \mathrm{~min}$ of centrifugation at 15,000 rpm at $4^{\circ} \mathrm{C}$. The supernatant was subsequently collected and employed for Western blot analysis as described below.

Preparation of solubility-based fractionation from mouse brains. The frozen brain tissues were sequentially extracted as previously described (19). At each step, sonication [40 sec at an amplitude of 20 using a Vibra Cell, VC130; Sonics \& Materials, USA)] in an appropriate buffer was followed by $1 \mathrm{~h}$ of centrifugation at $100,000 \mathrm{xg}$ at $4^{\circ} \mathrm{C}$. The supernatant was removed and the pellet was sonicated in the next solution in the sequential extraction process. For the four-step extraction, the sonication of frozen brain tissue samples $(100 \mathrm{mg})$ commenced in TBS (20 mM Tris and $137 \mathrm{mM} \mathrm{NaCl}, \mathrm{pH} 7.6)$ containing protease inhibitors (protease inhibitor cocktail; Sigma-Aldrich, USA) (extraction step 1). The next three sequential extraction steps used $1 \%$ Triton X-100 in TBS with protease inhibitors (extraction step 2), $2 \%$ aqueous SDS with the same protease inhibitors (extraction step 3), and 70\% formic acid in water (extraction step 4). Each fraction was then stored at $-80^{\circ} \mathrm{C}$ until further analysis.

Western and slot blot analyses. For Western blot analysis, protein prepared from the brain was separated via gradient (4-20\%) SDS-polyacrylamide gel electrophoresis (SDS-PAGE) for $3 \mathrm{~h}$. The resolved proteins were then transferred to a nitrocellulose membrane for $2 \mathrm{~h}$ at $40 \mathrm{~V}$. Each membrane was separately incubated with a 1:1,000 dilution of primary antibody to A $\beta-42$ (Chemicon, USA), synaptophysin (SigmaAldrich), or actin (Sigma-Aldrich) overnight at $4^{\circ} \mathrm{C}$. The membranes were then washed in washing buffer $(137 \mathrm{mM}$ $\mathrm{NaCl}, 2.7 \mathrm{mM} \mathrm{KCl}, 10 \mathrm{mM} \mathrm{Na} \mathrm{HPO}_{4}, 2 \mathrm{mM} \mathrm{KH} \mathrm{PO}_{4}$ and $0.05 \%$ Tween-20) and incubated with a 1:1,000 dilution of horseradish peroxidase (HRP)-conjugated goat anti-rabbit IgG (Zymed, USA) at room temperature for $2 \mathrm{~h}$. Blots were developed with a Chemiluminescence Reagent Plus kit (Amersham Pharmacia Biotech, USA). For the slot blot analysis, proteins prepared from the mouse brain samples were transferred to a nitrocellulose membrane using a Slot Blot kit (Amersham Pharmacia Biotech). Anti-A $\beta-42$ was applied in accordance with the manufacturer's recommendations to specifically detect $A \beta-42$ on a slot blot. Finally, each blot was developed 
using Nitro Blue tetrazolium chloride (NBT) with 5-bromo4-chloro-3'-indolyphosphate p-toluidine salt (BCIP) as the substrate.

Immunohistochemistry. Sixteen 8-month-old mice were used for synaptophysin immunostaining analysis: four hAPPsw $+\mathrm{hPS} 2 \mathrm{~m}$, four NSE-hAPPsw, four NSE-hPS2m, and four Non-Tg mice. These mice were perfused as previously described (20). After perfusion, the brain tissue was fixed for $12 \mathrm{~h}$ in $5 \%$ formalin at $4^{\circ} \mathrm{C}$, and then sequentially transferred to sucrose solutions of 10,20 and $30 \%$. Sections $(20 \mu \mathrm{m})$ were prepared and pretreated for $1 \mathrm{~h}$ at room temperature with PBS-blocking buffer containing $10 \%$ goat serum. Each section was separately incubated with a 1:100 dilution of primary rabbit polyclonal anti-synaptophysin antibody (Sigma-Aldrich) in blocking buffer overnight at $4^{\circ} \mathrm{C}$. The sections were washed in washing buffer, then incubated with a 1:2,500 dilution of the secondary antibody (HRP-conjugated goat anti-rabbit IgG; Zymed) for $2 \mathrm{~h}$ at room temperature. Synaptophysin protein in the brain tissue was detected by the development of color using stable 3,3'-diaminobenzidine (DAB) (Invitrogen, USA).

Cell culture and $A \beta-42$ peptide treatment. SK-N-MC human neuroepitheliomal cells were maintained for 24-36 h in Dulbecco's modified Eagle's medium (Gibco-BRL, USA) containing $10 \%$ fetal bovine serum, $1 \%$ non-essential amino acids, $2 \mathrm{ml} \mathrm{L}$-glutamine, $100 \mathrm{IU} / \mathrm{ml}$ penicillin and $100 \mu \mathrm{g} / \mathrm{ml}$ of streptomycin. Firstly, the A $\beta-42$ peptide (Sigma-Aldrich) was prepared by dissolving lyophilized $A \beta-42$ in dimethylsulfoxide at a concentration of $100 \mu \mathrm{M}$ and these peptides in solution were aggregated for $24 \mathrm{~h}$ at $37^{\circ} \mathrm{C}$. In order to treat the $\mathrm{A} \beta-42$ peptides into cells, SK-N-MC cells were seeded at a density of $2 \times 10^{6}$ cells per $100-\mathrm{mm}$-diameter dish. After reaching $80-90 \%$ confluence, aggregated $A \beta-42$ peptide was added at 10 or $100 \mathrm{nM}$, and the cells were incubated for an additional $24 \mathrm{~h}$ at $37^{\circ} \mathrm{C}(21)$. Protein samples were prepared from these cells using the afore-mentioned method for protein extraction from the mouse brains.

Statistical analysis. One-way ANOVA was used to determine whether significant differences existed between the Non-Tg and Tg groups (SPSS for Windows, Release 10.10, Standard Version, Chicago, IL). Additionally, differences in the responses of single Tg (NSE-hAPPsw and NSE-hPS2m) and hAPPsw+hPS2m double Tg mice were evaluated via a post-hoc test (SPSS for Windows, Release 10.10, Standard Version, Chicago, IL) of the variance and significance levels. All values were reported as the mean \pm standard deviation. A P-value of $<0.05$ was considered significant.

\section{Results}

Identification of Tg mice. The A $\beta-42$ peptide level in the brains of different mouse AD models can differ depending on the inserted gene and the physiological condition of the mice $(17,18)$. Prior to investigating whether the $A \beta-42$ peptide could induce alterations of synaptophysin under in vivo conditions, appropriate animal models harboring different levels of $A \beta-42$ peptide in the brain were obtained via mating. For this mating, two AD models including NSE-hAPPsw Tg mice and

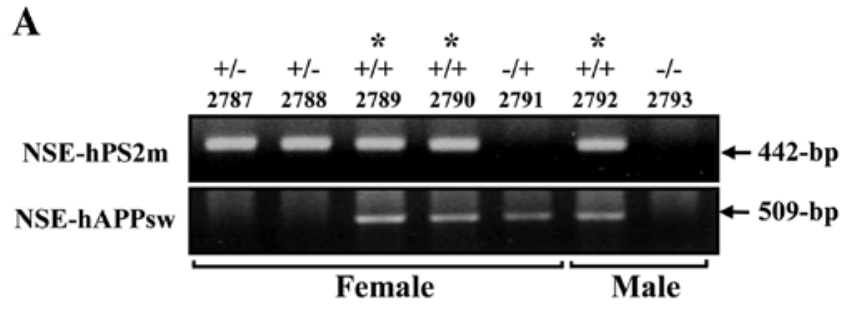

B

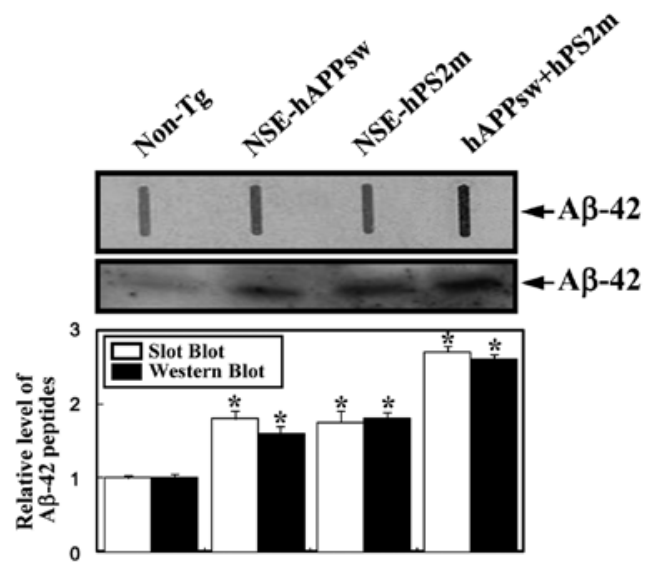

Figure 1. Identification of $\mathrm{Tg}$ mice and analyses of $\mathrm{A} \beta-42$ deposition. (A) DNA-PCR was conducted with genomic DNA isolated from the tails of founder mice, and the 442-bp- and 509-bp products for NSE-hPS2m (upper panel) and NSE-hAPPsw (lower panel), respectively, are shown. Four genotype progeny segregated from the cross between two lines are indicated (-/-, Non-Tg; -/+, NSE-hAPPsw; +/-, NSE-hPS2m; +/+, hAPPsw+hPS2m). (B) Slot blot and Western blot analyses of $A \beta-42$. Upper panel, slot blot of $\mathrm{A} \beta-42$. The nitrocellulose filters transferred $2 \mu \mathrm{g}$ of protein from the brains of all four genotype progenies were incubated with the anti-human A $\beta-42$ antibody. Middle panel, Western blot of A $\beta-42$. Lysates were prepared from the brains of four genotype progenies. Protein $(50 \mu \mathrm{g})$ was separated via $10-20 \%$ SDS-PAGE and transferred to nitrocellulose membranes. $\mathrm{A} \beta-42$ was detected with antibodies raised against human $A \beta-42$ followed by anti-mouse-HRP. Lower panel: protein levels were quantified using a Kodak electrophoresis documentation and analysis system. The values are expressed as the means $\pm \mathrm{SD}$. ${ }^{*} \mathrm{P}<0.05$ is the significance level relative to Non-Tg mice.

NSE-hPS2m Tg mice were selected from five AD models previously developed in our laboratory $(17,18)$. In order to identify the four different genotypes in the offspring produced from the mating between the male NSE-hAPPsw Tg mice and female NSE-hPS2m Tg mice, DNA-PCR analysis using the genomic DNA isolated from the tail of the 4-week founder mice was performed. Following electrophoresis of the PCR products, the hPS2m- and hAPPsw-specific PCR products were detected on agarose gels as bands of 442 and 509-bp, respectively. A total of seven founder mice were identified as Tg mice; three hAPPsw+hPS2m double Tg mice (\#2789, \#2790, and \#2792), an NSE-hAPPsw single Tg (\#2791) mouse, two NSE-hPS2m single Tg mice (\#2787 and 2788), and a Non-Tg mouse (\#2793) (Fig. 1A). These results reflect the successful acquisition of the four different genotypes, and demonstrate that the NSE-hAPPsw and NSE-hPS2m Tg mice successfully transferred the transgene into their progenies in a Mendelian inheritance manner.

Deposition of $A \beta-42$ peptides in the brains of four different mouse genotypes. To compare the deposition of $\mathrm{A} \beta-42$ 
peptides in the brains of four different mouse genotypes, the levels of brain $A \beta-42$ peptides were quantified at 8 months of age via Western blot and slot blot analyses. As demonstrated in Fig. $2 B$, the levels of $A \beta-42$ peptides were significantly greater in the brains of the single NSE-hAPPsw and NSE-hPS $2 \mathrm{~m} \mathrm{Tg}$ mice relative to those of the Non-Tg mice. Additionally, the levels of $A \beta-42$ peptides in the brains of the hAPPsw+hPS $2 m$ double Tg mice were 2- to 3-fold greater than those detected in the brains of the single NSE-hAPPsw and NSE-hPS2m Tg mice. However, no differences in the $A \beta-42$ peptide levels were observed between the brains of the single NSE-hAPPsw and NSE-hPS2m Tg mice (Fig. 1B). These observations in the four mouse genotypes may reflect different levels of $A \beta-42$ peptides in their brains. In particular, the hAPPsw $+h P S 2 m$ double $\mathrm{Tg}$ mice displayed the highest levels of $A \beta-42$ peptides among the four mouse genotypes, respectively.

Effects of A $\beta-42$ peptides on the level of soluble and total synaptophysin. In order to determine whether the $A \beta-42$ peptides, which are known to induce cortical and hippocampal disorganization, would affect synaptophysin level, the soluble protein and total protein levels of synaptophysin were measured via Western blot and immunohistochemical analyses in order to detect the soluble form of the specific protein, as well as the localization and distribution of the total protein, respectively. The level of the soluble form of synaptophysin was significantly lower in hAPPsw+hPS2m double Tg mice relative to the single and Non-Tg littermate mice. By way of contrast, no significant changes were noted in the levels of synaptophysin expression between the brains of the single and Non-Tg mice, although the level in the single $\mathrm{Tg}$ mice was increased slightly relative to the Non-Tg mice (Fig. 2A). However, in immunohistochemical analysis, the immunoreactivity of total synaptophysin within the cortex and hippocampus regions of the brains between the double hAPPsw+hPS2 $\mathrm{m}$ and control $\mathrm{Tg}$ mice (NSE-hAPPsw, NSE-hPS2m, and Non-Tg mice) did not differ (Fig. 2B). Therefore, these results suggest that the biochemical properties, such as the solubility of synaptophysin may be altered in the brains of double hAPPsw+hPS $2 \mathrm{~m} \mathrm{Tg}$ mice with high levels of deposited A $\beta-42$ peptides, although the amount of total synaptophysin proteins remains uniform.

Effects of A $\beta-42$ peptides on the solubility of synaptophysin. The next experiment addressed the hypothesis that $A \beta-42$ deposition in the brains of mouse models of AD induces alterations in the biochemical properties of synaptophysin without affecting its quantity. To test this hypothesis, the four soluble synaptophysin fractions were extracted from the brains of the progeny of the four mouse genotypes, and their levels were ascertained via Western blot analysis. In the TBS fraction harboring highly soluble proteins, synaptophysin levels in the hAPPsw+hPS2m double Tg mice was markedly reduced as compared with the single NSE-hAPPsw, NSE-hPS2m, and Non-Tg mice (Fig. 3A). However, the level of synaptophysin in the $70 \%$ formic acid fraction, which harbored poorly soluble proteins, was higher in the brains of the hAPPsw $+\mathrm{hPS} 2 \mathrm{~m}$ double Tg mice than in the single NSE-hAPPsw, NSE-hPS2m, and Non-Tg mice (Fig. 3A). By way of contrast, we detected no significant differences between the hAPPsw+hPS2 $\mathrm{m}$ double $\mathrm{Tg}$ mice and the control mice with regard to synaptophysin levels
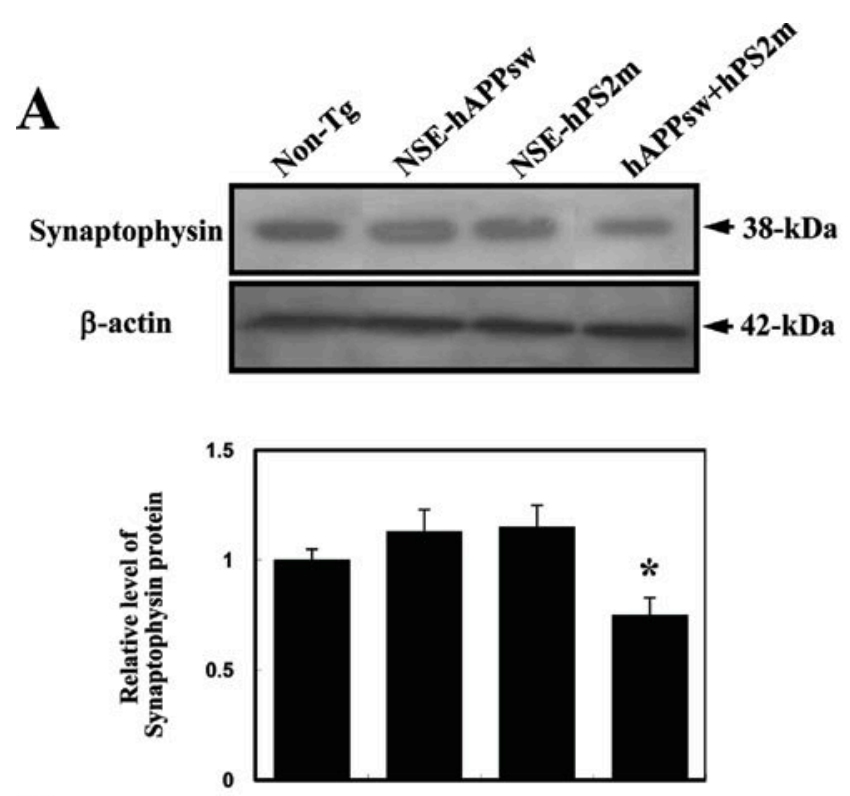

B

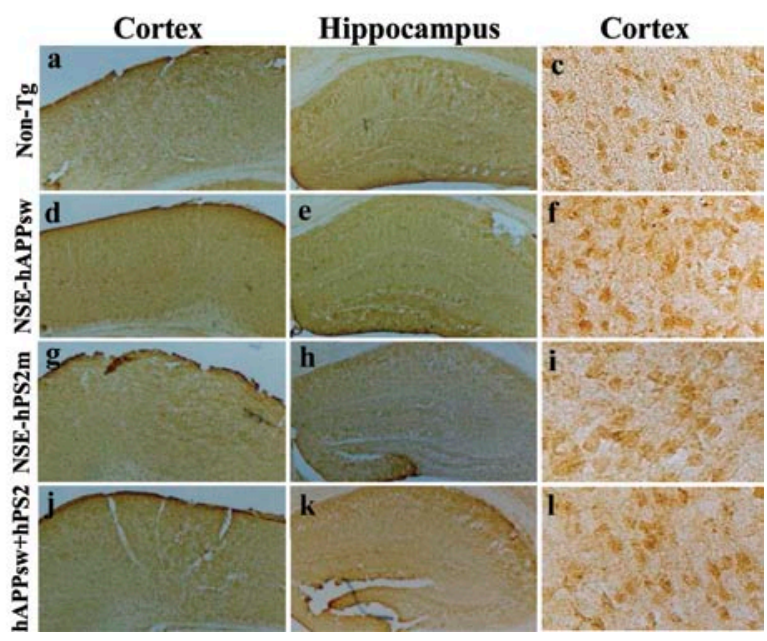

Figure 2. Levels of soluble synaptophysin in the brains of the four mouse genotypes. (A) Western blot analysis. This analysis was conducted as described in Materials and methods. The values are expressed as the means \pm SD. ${ }^{*} \mathrm{P}<0.05$ is the significance level compared to Non-Tg mice. (B) Immunostaining of synaptophysin. Sections of the brains $(20 \mu \mathrm{m})$ from four genotype progenies were incubated with the anti-synaptophysin primary antibody and horseradish peroxidase-conjugated goat anti-rabbit IgG secondary antibody. The resultant tissues were developed with DAB and viewed under a microscope; $\mathrm{x} 40$ magnification in the cortex and hippocampus $(\mathrm{a}, \mathrm{b}$, $\mathrm{d}, \mathrm{e}, \mathrm{g}, \mathrm{h}, \mathrm{j}$ and k); x200 magnification in the cortex (c, f, i and 1).

from the Triton X-100- and SDS-soluble fractions containing proteins of intermediate solubility (Fig. 3). These results are consistent with the suggestion that copious levels of $A \beta-42$ peptides may induce a significant reduction in synaptophysin solubility. These changes were only observed in the TBS and formic acid fractions in the brains of hAPPsw+hPS2 $m$ double Tg mice.

Verification of the effects of $A \beta-42$ peptides on synaptophysin solubility using $S K-N-M C$ cells. Finally, in an effort to confirm that the effects of the A $\beta-42$ peptide observed in the genotypically different mice could be detected in vitro, the synaptophysin levels were determined in the four soluble fractions collected from the SK-N-MC cells after $24 \mathrm{~h}$ of 
A

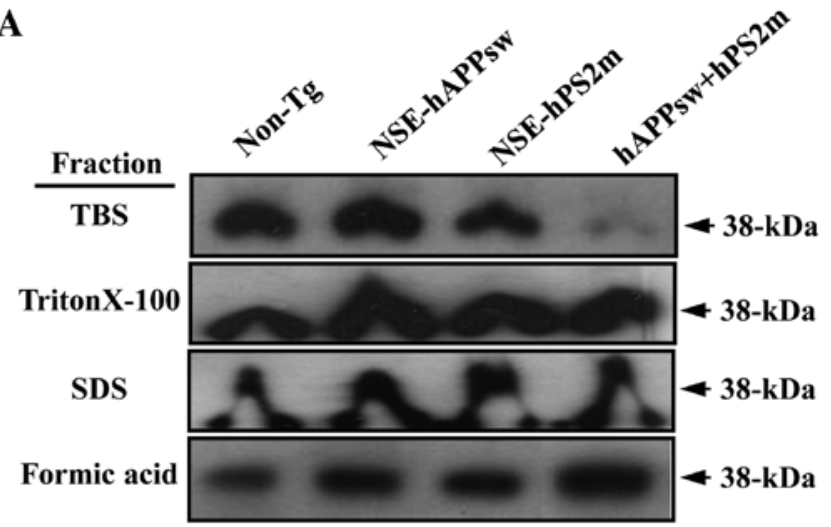

B

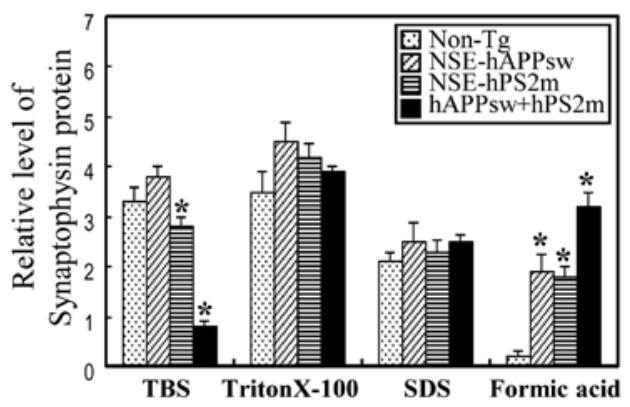

Figure 3. Alteration of synaptophysin levels in four-different solubility fractions extracted from brains of four mouse genotypes. For the four-step extraction, sonication of the frozen brains $(100 \mathrm{mg})$ began in TBS containing protease inhibitors, as described in Materials and methods. The next three sequential extraction steps used $1 \%$ Triton X-100 in TBS with protease inhibitors, $2 \%$ SDS in water with protease inhibitors, and $70 \%$ formic acid in water. The synaptophysin levels in each fraction were analyzed via Western blotting using a synaptophysin antibody. Data are expressed as the means $\pm \mathrm{SD}$ from three replicates. ${ }^{*} \mathrm{P}<0.05$ is the significance level compared to the Non-Tg mice.

treatment with $\mathrm{A} \beta-42$ peptides. As shown in Fig. $4 \mathrm{~A}$, the high concentration $(100 \mathrm{nM})$ of $\mathrm{A} \beta-42$ peptide induced neuronal cell death, whereas the low dose $(10 \mathrm{nM})$ did not induce any detectable changes. Additionally, Western blot analysis rarely detected synaptophysin in the TBS fraction, and the synaptophysin levels in the Triton X-100 fraction were slightly reduced in the $A \beta-42$-treated relative to the vehicle-treated cells (Fig. 4B). In the formic acid soluble fraction, the highest synaptophysin levels were observed in cells treated with $100 \mathrm{nM}$, followed by $10 \mathrm{nM}$ and vehicle treatment. By way of contrast, we noted no differences between the $A \beta-42$-treated and vehicle-treated cells with regard to synaptophysin levels in the SDS fraction (Fig. 4B). The results support the suggestion that treatment with $A \beta-42$ peptides significantly enhances the insolubility of synaptophysin in the neuroblastoma cells, which is similar to the pattern observed in the brains of hAPPsw+hPS2m double Tg mice.

\section{Discussion}

$\mathrm{AD}$ is a neurodegenerative disorder that features deposits of amyloid plaques and neurofibrillary tangles within the cortex and hippocampus of the brain $(22,23)$. The formation of the neurofibrillary tangles, the elevation of phosphorylated Tau, and the accumulation of $A \beta-42$ peptides in the neuronal cells
A

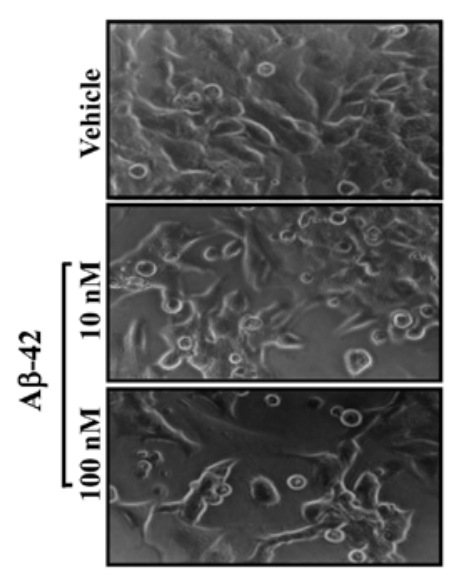

B
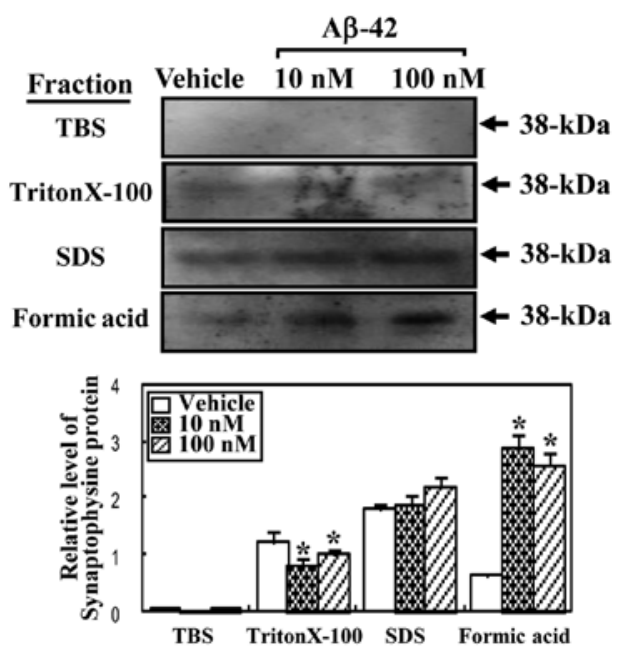

Figure 4. Alteration of synaptophysin levels in four-different solubility fractions extracted from SK-N-MC cells after A $\beta-42$ treatment. (A) The cells were exposed to 10 or $100 \mathrm{nM} \mathrm{A} \beta-42$ peptide for $24 \mathrm{~h}$ at $37^{\circ} \mathrm{C}$. In the vehicle group, the cells were exposed to dimethylsulfoxide for the same period of time. A $\beta-42$-treated cells were observed under a microscope at $x 40$ magnification. (B) Cell extraction and Western blot analysis were similarly conducted in brain samples from the four mouse genotypes. ${ }^{*} \mathrm{P}<0.05$ is the significance level compared to the vehicle-treated group.

of AD brains significantly inhibit intracellular transport, cellular geometry, and neuronal viability in the neuronal cells $(4,5,24-26)$. Ultimately, these events result in apoptotic death of neuronal cells, and prevent the communication of neuronal cells (27).

In the process of communication between neuronal cells, signals from the presynaptic neuron can be transmitted into the postsynaptic neuron by the opening of an ion-channel that is bound to the neurotransmitter-receptor in the membrane of the postsynaptic neuron. Synaptophysin is crucial to exocytosis during the process of neurotransmitter release, facilitating the fusion of the synaptic vesicles to the presynaptic membrane $(4,5)$. In AD and Parkinson's disease (PD), the release of neurotransmitters from the neuronal cells is significantly reduced or impaired relative to that observed in normal neuronal cells (28). In particular, these alterations of neurotransmitter regulation are correlated strongly with mutations in genes encoding for Presenilin in AD, and Parkin, DJ-1, PINK1, and LRRK2 in PD $(28,29)$. However, no studies 
have yet been conducted regarding the correlation between the A $\beta-42$ peptides increased by overexpression of the hPS $2 \mathrm{~m}$ or hAPPsw gene and the biochemical properties of synaptophysin. Therefore, it was necessary to determine whether or not the biophysical properties of synaptophysin can be altered by $\mathrm{A} \beta-42$ peptides in an $\mathrm{AD}$ animal model harboring damaged neuronal cells.

The present study was conducted with hAPPsw+hPS2m $\mathrm{Tg}$, NSE-hAPPsw Tg, NSE-hPS2m Tg and Non-Tg mice to evaluate the changes in the levels of synaptophysin in the brains of the genotypically different AD models. Significant behavioral dysfunctions in the water maze test, and the brain levels of $A \beta-42$, caspase- 3 and Cox- 2 proteins have been demonstrated in single NSE-hAPPsw or NSE-hPS2m Tg 12-month-old mice (17). Furthermore, the behavioral deficits in the hAPPsw+hPS2 $\mathrm{m}$ double Tg mice developed much earlier than in their single and Non-Tg littermate progenies at 8 months of age (data not shown). These double Tg mice harbored $40-50 \%$ more $A \beta-42$ peptides in their brains (Fig. 1B). Also, previous studies have reported that the hAPPsw+hPS1 double Tg mice produced from a cross between line $\mathrm{Tg} 2576$ and a mutant PS1M146L Tg line developed fibrillar $A \beta$ deposits within the cortex and hippocampus more rapidly and exuberantly compared to their single $\mathrm{Tg}$ $\mathrm{Tg} 2576$ littermates $(30,31)$. The current results obtained with the hAPPsw+hPS2m double Tg mice are consistent with these results.

Also, in our study, the levels of synaptophysin among the hAPPsw+hPS2m double, single NSE-hAPPsw and NSE-hPS $2 \mathrm{~m} \mathrm{Tg}$, and Non-Tg AD mice were examined to discern if there were any differences, because of the controversy of this issue. Specifically, SY-IR data from the various AD models are inconsistent (32). In a study using one of the most well-known models, SY-IR in the dentate gyrus of the brains of Tg mice expressing APP695 and APP751 wild-type under the control of the NSE promoter was found to be significantly decreased despite $A \beta-42$ deposition (32). Also, Mucke et al (12) suggested that the density of SYN-IR presynaptic terminals in various APP Tg mice is not associated with APP levels or A $\beta$ plaques. These results collectively suggest that soluble (non-fibrillar) $A \beta$ could induce synaptic pathology independent of neuritic plaque formation (32). Furthermore, previous investigations with Tg2576+PS1 $\mathrm{Tg}$ mice demonstrated no difference in the SYN-IR in the neocortex and hippocampus between 3-12-month-old single and Non-Tg mice (16). In this study, immunohistochemical analyses revealed that SYN-IR was consistently maintained in the four different mouse genotypes. However, our study was focused on the correlation between $A \beta-42$ peptides and the biochemical properties of synaptophysin. Of these properties, the solubility of the protein was selected as a first target in order to investigate the alteration of synaptophysin. The proteins used this study were sequentially extracted from brain tissue and SK-N-MC cells according to their solubility in TBS, $1 \%$ Triton X-100, 2\% SDS and 70\% formic acid (19). As shown Fig. 2A, the protein levels of soluble synaptophysin were decreased in the hAPPsw+hPS $2 \mathrm{~m}$ double Tg mice containing high $\mathrm{A} \beta-42$ peptides compared to the single $\mathrm{Tg}$ and Non-Tg mice. In contrast, the insoluble synaptophysin in the $70 \%$ formic acid fraction was significantly greater in hAPPsw+hPS2m double than in the single and Non-Tg mice. These findings suggest the possibility that the $A \beta-42$ deposition in the brains of AD mice could induce altered synaptophysin solubility. Our results are in agreement with a previous study in which $A \beta-42$ peptides caused a decreased solubility of Tau along with the generation of paired helical filaments (33).

Furthermore, the changes in synaptophysin insolubility are speculated to affect neuronal vesicle docking and fusion processes, leading to inhibition of neurotransmittor release $(34,35)$. In effect, the increase in the synaptophysin protein solubility, which acts as a mediator of the interaction and fusion pore between the synaptic vesicle and the plasma membrane, would inhibit the formation of the interaction and fusion pore between the neuronal vesicle and the plasma membrane, subsequently impairing neuronal function $(34,35)$. Also, this interaction and fusion could be regulated with the intracellular calcium concentration influx through the voltage-gated calcium channel. High concentrations of calcium accelerated the recruitment of release-ready vesicles as well as the recovery of the vesicle pool in rest periods (36). Therefore, in order to understand the detail mechanism of synaptophysin's solubility, the physiological characteristics of the correlation between synaptophysin and calcium need to be determined because these results may be used to develop novel therapeutic drugs.

Taken together, our results suggest that alteration of the solubility of synaptophysin affected by $A \beta-42$ peptides may be considered one of the causes of the impairment of neurotransmitter release. Also, these results are strongly expected to provide a vital clue for the development of novel drugs and therapies for AD.

\section{Acknowledgements}

This study was supported by a National Research Foundation of Korea (NRF) grant funded by the Korean government (MEST) (MRC, 2010-0029480).

\section{References}

1. Jahn R, Schiebler W, Ouimet C and Greengard P: A 38,000dalton membrane protein (p38) present in synaptic vesicles. Proc Natl Acad Sci USA 82: 4137-4141, 1985.

2. Wiedenmann B and Franke WW: Identification and localization of synaptophysin, an integral membrane glycoprotein of $\mathrm{Mr}$ 38,000 characteristic of presynaptic vesicles. Cell 41: 1017-1028, 1985.

3. Hong A, Gould VE, Grimelius L, Franke WW, Falkermer S and Chejfec G: Tissue fixation methods alter the immunohistochemical demonstrability of synaptophysin. Ultrastruct Pathol 12: 673-678, 1988.

4. Rehm H, Wiedenmann B and Betz H: Molecular characterization of synaptophysin, a major calcium-binding protein of the synaptic vesicle membrane. EMBO J 5: 535-541, 1986.

5. Thomas L, Hartung K, Langosch D, Rehm H, Bamberg E, Franke WW and Betz H: Identification of synaptophysin as a hexameric channel protein of the synaptic vesicle membrane. Science 242: 1050-1053, 1988.

6. Knaus P, Betz H and Rehm H: Expression of synaptophysin during postnatal development of the mouse brain. J Neurochem 47: 1302-1304, 1986.

7. Leclerc N, Beesley PW, Brown I, Colonnier M, Gurd JW, Paladino T and Hawkes R: Synaptophysin expression during synaptogenesis in the rat cerebellar cortex. J Comp Neurol 280: 197-212, 1989. 
8. Benson CG, Gross JS, Suneja SK and Potashner SJ: Synaptophysin immunoreactivity in the cochlear nucleus after unilateral cochlear or ossicular removal. Synapse 25: 243-257, 1997.

9. Brock TO and O'Callaghan JP: Quantitative changes in the synaptic vesicle proteins synapsin I and p38 and the astrocytespecific protein glial fibrillary acidic protein are associated with chemical-induced injury to the rat central nervous system. J Neurosci 7: 931-942, 1987.

10. Sokolowski BHA and Cunningham AM: Patterns of synaptophysin expression during development of the inner ear in the chick. J Neurobiol 38: 46-64, 1999.

11. Games D, Adams D, Alessandrini R, Barbour R, Berthelette P, Berthelette P, Blackwell C and Carr T: Alzheimer-type neuropathology in transgenic mice overexpressing V717F beta-amyloid precursor protein. Nature 373: 523-527, 1995.

12. Mucke L, Masliah E, Johnson W, Ruppe M, Alford M, Rockenstein E, Forss-Petter S, Pietropaolo M, Mallory M and Abraham C: Synaptophysin effects of human amyloid beta protein precursor in the cortex of transgenic mice. Brain Res 666: 151-167, 1994.

13. Dodart JC, Mathis C, Saura J, Bales KR, Paul SM and Ungerer A Neuroanatomical abnormalities in behaviorally characterized APP (V717F) transgenic mice. Neurobiol Dis 7: 71-85, 2000

14. Irizarry MC, Soriano F, McNamara M, Page KJ, Schenk D, Games D and Hyman BT: Abeta deposition is associated with neuropil changes, but not with overt neuronal loss in the human amyloid precursor protein V717F (PDAPP) transgenic mice. J Neurosci 17: 7053-7059, 1997.

15. Irizarry MC, McNamara M, Fedorchak K, Hsiao K and Hyman BT: APPsw transgenic mice develop age-related A beta deposits and neurophil abnormalities, but no neuronal loss in CA1. J Neuropathol Exp Neurol 56: 965-973, 1997.

16. Takeuchi A, Irizarry MC, Duff K, Saido TC, Ashe Hsiao K, Hasegawa M, Mann D, Hyman BY and Iwatsubo T: Age-related amyloid beta deposition in transgenic mice overexpressing both Alzheimer mutant presenilin 1 and amyloid beta precursor protein Swedish mutant is not associated with global neuronal loss. Am J Pathol 157: 331-339, 2000.

17. Hwang DY, Cho JS, Kang TS, Hwnag JH, Lim CH, Kang HK, Goo JS, Lee MR, Lim HJ, Min SH, Cho JY, Hong JT, Song CW, Paik SG, Cho JS and Kim YK: Aberrant expressions of pathogenic phenotype in Alzheimer's diseased transgenic mice carrying NSE-controlled APPsw. Exp Neurol 1: 20-32, 2003

18. Hwang DY, Chae KR, Kang TS, Hwnag JH, Lim CH, Kang HK, Goo JS, Lee MR, Lim HJ, Min SH, Cho JY, Hong JT, Song CW, Paik SG, Cho JS and Kim YK: Alteration in behavior, amyloid $\beta-42$, caspase- 3 , and Cox-2 in mutant PS2 transgenic mice model of Alzheimer's disease. FASEB J 16: 805-813, 2002.

19. Kawarabayashi T, Younkin LH, Saido TC, Shoji M, Ashe KH and Younkin SG: Age-dependent changes in brain, CSF, and plasma amyloid $\beta$ protein in the Tg 2576 transgenic mouse models of Alzheimer's disease. J Neurosci 21: 372-381, 2001.

20. Van de Craen M, de Jonghe C, van den Brande I, Declercq W, van Gassen G, van Criekinge W, Vanderhoeven I, Fiers W, van Broeckhoeven C, Hendriks L and Vandenabeele P: Identification of caspases that cleave presenilin-1 and presenilin-2. Five presenilin-1 (PS1) mutations do not alter the sensitivity of PS1 to caspases. FEBS Lett 445: 149-154, 1999.
21. Bergamaschini L, Donarini C, Rossi E, De Luigi A, Vergani C and De Simoni MG: Heparin attenuates cytotoxic and inflammatory activity of Alzheimer amyloid- $\beta$ in vitro. Neurobiol Aging 23: 531-536, 2002.

22. Smale G, Nichols NR, Brady DR, Finch CE and Horton WE Jr: Evidence for apoptotic cell death in Alzheimer's disease. Exp Neurol 133: 225-230, 1995.

23. $\mathrm{Su} \mathrm{JH}$, Anderson AJ, Cummings BJ and Cotman CW: Immunohistochemical evidence for apoptosis in Alzheimer's disease. Neuroreport 5: 2529-2533, 1994.

24. Arnold SE, Hyman BT, Flory J, Damasio AR and Van Hoesen GW: The topographical and neuroanatomical distribution of neurofibrillary tangles and neuritic plaques in the cerebral cortex of patients with Alzheimer's disease. Cereb Cortex 1: 103-116, 1991.

25. Lee VMY, Balin BJ, Otvos L Jr and Trojanowski JQ: A68: a major subunit of paired helical filaments and derivative forms of normal tau. Science 251: 675-678, 1991.

26. Morris JC, Storandt M, Mckeel DW Jr, Rubin EH, Price JL, Grant EA and Berg L: Cerebral amyloid deposition and diffuse plaques in 'normal' aging: evidence for presymtomatic and very mild Alzheimer's disease. Neurology 46: 707-719, 1996.

27. Troncoso JC, Sukhov RR, Kawas CH and Koliatsos VE: In situ labeling of dying cortical neurons in normal aging and in Alzheimer's disease: correlations with senile plaque and disease progression. J Neuropathol Exp Neurol 55: 1134-1142, 1996.

28. Shen J: Impaired neurotransmitter release in Alzheimer's and Parkinson's diseases. Neurodegener Dis 7: 80-83, 2010.

29. Zhang C, Wu B, Beglopoulos V, Wines-Samuelson M, Zhang D, Dragatsis I, Südhof TC and Shen J: Presenilins are essential for regulating neurotransmitter release. Nature 460: 632-636, 2009.

30. Borchelt DR, Ratovitski T, van Lare J, Lee MK, Gonzales V, Jenkins NA, Copeland NG, Price DL and Sisodia SS: Accelerated amyloid deposition in the brains of transgenic mice coexpressing mutant presenilin 1 and amyloid precursor proteins. Neuron 19: 939-945, 1997.

31. Holcomb L, Gordon MN, McGowan E, Yu X, Benkovic S, Jantzen P, Wright K, Saad I, Mueller R, Morgan D, Sanders S, Zehr C, O'Campo K, Hardy J, Prada CM, Eckman C, Younkin S, Hsiao K and Duff K: Accelerated Alzheimer-type phenotype in transgenic mice carrying both mutant amyloid precursor protein and presenilin 1 transgenes. Nat Med 4: 97-100, 1998.

32. King DL and Arendash GW: Maintained synaptophysin immunoreactivity in $\mathrm{Tg} 2576$ transgenic mice during aging: correlations with cognitive impairment. Brain Res 926: 58-68, 2002

33. Ferrari A, Hoerndli F, Baechi T, Nitsch RM and Götz J: betaamyloid induces paired helical filament-like tau filaments in tissue culture. J Biol Chem 278: 40162-40168, 2003.

34. Scheller RH: Membrane trafficking in the presynaptic nerve terminal. Neuron 14: 893-897, 1995.

35. Sudhof TC: The synaptic vesicle cycle: a cascade of proteinprotein interactions. Nature 375: 645-53, 1995.

36. Neher E and Sakaba T: Multiple roles of calcium ions in the regulation of neurotransmitter release. Neuron 59: 861-872, 2008. 